\title{
EVALUATION OF POLYPHENOLIC PROFILE AND ANTIOXIDANT ACTIVITY FOR SOME SALVIA SPECIES
}

\author{
DANIELA HANGANU ${ }^{1}$, NELI-KINGA OLAH ${ }^{2}$, CARMEN ELENA POP $^{1}{ }^{*}$, LAURIAN VLASE $^{1}$, \\ ILIOARA ONIGA ${ }^{1}$, NINA CIOCARLAN ${ }^{3}$, ALINA MATEI $^{4}$, CRISTINA PUȘCAȘ ${ }^{4}$, RADU \\ SILAGHI-DUMITRESCU ${ }^{4}$, DANIELA BENEDEC ${ }^{1}$
}

${ }^{I}$ Faculty of Pharmacy, "Iuliu Haţieganu” University of Medicine and Pharmacy, 12 I. Creangă Street, Cluj-Napoca, Romania ${ }^{2}$ Faculty of Pharmacy, "Vasile Goldiş" West University of Arad, 86 L. Rebreanu Street, Arad, Romania; SC PlantExtrakt SRL, Rădaia, Cluj County, Romania

${ }^{3}$ Botanical Garden, Sciences Academy Republic of Moldova, Chişinău, Republic of Moldova

4 "Babeș-Bolyai" University, 11 A. Janos Street, Cluj-Napoca, Romania

*corresponding author: carmen.pop@umfcluj.ro

\begin{abstract}
The polyphenolic composition and antioxidant capacity of some Salvia L. species (S. aetiopsis, S. austriaca, S. sclarea, S nutans, S. verticilatta and $S$. nemorosa) were the goals of this study. Analysis of polyphenols was performed by a HPLC/UV/MS method and was achieved on the ethanolic extracts obtained from aerial parts of the plants, collected from the spontaneous Flora of Republic of Moldova. The total polyphenolic, flavonoids and caffeic acid derivatives content were measured by spectrophotometric methods. In vitro antioxidant activity of these extracts was evaluated using DPPH $(\alpha, \alpha-$

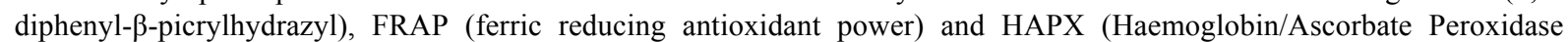
Activity Inhibition) methods. The polyphenolic profile of these species revealed the common components (caffeic acid, $p$ cumaric acid, isoquercitrin, hyperoside, luteolin, apigenin) and other non-common compounds (caftaric acid, chlorogenic acid, ferulic acid, rutin, quercitrin, quercetin, kaempferol). The highest antioxidant capacity was revealed by $S$. verticillata. All studied Salvia species contain significant amounts of polyphenolic compounds $(22.25-118.75 \mathrm{mg}$ GAE/g dry weight material plant) and may be used as important source of natural antioxidants along with the most famous $S$. officinalis.
\end{abstract}

\section{Rezumat}

Obiectivele acestui studiu au vizat evidențierea profilului polifenolic și capacitatea antioxidantă a unor specii de Salvia L. ( $S$. aetiopsis, S. austriaca, S. sclarea, S. nutans, S. verticilatta și $S$. nemorosa). Analiza polifenolilor a fost realizată prin metoda HPLC/UV/MS, pe extracte etanolice obţinute din părţi aeriene ale plantelor recoltate din flora spontană a Republicii Moldova. Concentraţiile de polifenoli totali, flavonoide și derivați de acid cafeic au fost evaluate prin metode spectrofotometrice. Activitatea antioxidantă in vitro a fost evaluată utilizând metodele DPPH, FRAP și HAPX (inhibarea activității hemoglobinei/ascorbat peroxidazei). Profilul polifenolic al acestor specii a evidențiat componente comune (acid cafeic, acid $p$-cumaric, izoquercitrina, hiperozida, luteolina, apigenina), precum şi componente de diferențiere a speciilor (acid caftaric, acid clorogenic, acid ferulic, rutozida, quercitrina, quercetol, kempferol). Cea mai bună activitate antioxidantă a prezentat $S$. verticillata. Speciile de Salvia studiate conțin cantități semnificative de compuşi polifenolici $(22,25$ - 118,75 $\mathrm{mg} \mathrm{GAE} / \mathrm{g}$ produs vegetal uscat) și pot fi folosite ca surse importante de antioxidanți naturali, alături de specia oficinală $S$. officinalis.

Keywords: Salvia aetiopsis, S. austriaca, S. sclarea, S nutans, S. verticilatta, S. nemorosa, polyphenols, DPPH, FRAP, HAPX

\section{Introduction}

Polyphenols are secondary metabolites that are widely spread in the plant kingdom and are known for their antioxidative capacity, neutralizing free-radical responsible for cell damage. Thereby polyphenols may be utilized in prevention and treatment of a large array of freeradical mediated diseases. In recent decades, significant amounts of research have been carried out on natural polyphenol sources [1-4].

Salvia L. (Lamiaceae) is a large and diversified genus including approximately 90 species, of which almost 15 are largely distributed in South-eastern Europe, included Salvia officinalis (sage) which is the best known and most widely used medicinal plant [5]. Other Salvia species are important sources of active principles as well, but are less studied. Salvia species are generally known for their multiple pharmacological effects including antiproliferative, antiinflammatory, anti-nociceptive, antioxidant, antimicrobial, antimutagenic, anti-dementia, hypoglycaemic and hypolipidaemic effects [6].

Some studies showed that these activities depended on essential oil, polyphenolcarboxilic acids (caffeic acid, chlorogenic acid, ellagic acid, gallic acid, rosmarinic acid), flavonoids and tannin composition [7-12]. 
The goal of this paper was to evaluate the polyphenolic content and the antioxidant activity of six Salvia L. species from spontaneous Moldavian Flora (S. aetiopsis, S. austriaca, S. sclarea, S nutans, $S$. verticilatta and $S$. nemorosa), using three in vitro model systems, DPPH, FRAP and HAPX (Haemoglobin/ Ascorbate Peroxidase Activity Inhibition). The results of our research could be useful as scientific information on these species as potential sources of antioxidants.

\section{Materials and Methods}

\section{Experimental}

Chemicals and Apparatus. Ferulic, sinapic, gentisic, gallic acids, patuletin, luteolin were acquired from Roth (Karlsruhe, Germany); chlorogenic, $p$-coumaric, caffeic acids, rutin, apigenin, quercetin, isoquercitrin, quercitrin, hyperoside, kaempferol, myricetol, fisetin were purchased from Sigma (St. Louis, MO, USA); cichoric and caftaric acids were from Dalton (Toronto, ON, Canada). Sodium molybdate dihydrate, sodium nitrite, sodium hydroxide, sodium carbonate were purchased from Sigma-Aldrich (Steinheim, Germany). HPLC grade methanol, analytical grade ortho-phosphoric acid, hydrochloric acid, aluminium chloride, sodium acetate, ethanol and Folin-Ciocâlteu reagent were purchased from Merck (Darmstadt, Germany). DPPH', $\mathrm{ABTS}^{+}$ were obtained from Alfa-Aesar (Karlsruhe, Germany). Hydrogen peroxide, sodium ascorbate and bovine haemoglobin were purchased from Sigma-Aldrich (Steinheim, Germany). All spectrophotometric data were acquired using a Jasco V-530 UV-vis spectrophotometer (Jasco Int. Co. Ltd., Tokyo, Japan).

Plant material and extraction procedure. The aerial parts of the plants were collected in 2016, during the blooming period (June - July) from the North-eastern part of Republic of Moldova, Chişinău surroundings, N 4702'58.58"; E 28 52'42.65". Voucher specimens (No. 220 - 225) were deposited in the Herbarium of the Department of Pharmacognosy, Faculty of Pharmacy, Cluj-Napoca, Romania. The vegetal material was grinded to fine powder $(300 \mu \mathrm{m})$ after air drying at room temperature. The material was extracted at $60^{\circ} \mathrm{C}$ (on a water bath) with $70 \%$ ethanol for $30 \mathrm{~min}$. The supernatant was recovered after centrifugation at $4500 \mathrm{rpm}$ for $15 \mathrm{~min}$ [13-15].

HPLC Analysis. The chemical determination of polyphenols was achieved using an Agilent Technologies 1100 HPLC Series system coupled with an Agilent 1100 mass spectrometer (LC/MSD Ion Trap VL) equipped with degasser, binary gradient pump, column thermostat, autosampler and detector. For the separation, a reverse-phase analytical column was employed. The detection of the compounds was performed on both UV and MS mode. Calibration curves were used for the 20 reference phenolic standards (chlorogenic, $p$ coumaric, caffeic, cichoric, caftaric, ferulic, sinapic, gentisic gallic acids, rutin, quercetin, isoquercitrin, quercitrin, hyperoside, kaempferol, myricetol, fisetin, patuletin, apigenin, luteolin), in $0.5-50 \mu \mathrm{g} / \mathrm{mL}$ range with good linearity $\left(\mathrm{R}^{2}>0.999\right)$ for a five point plots. The data were processed using ChemStation and DataAnalysis software from Agilent $[16,17]$.

The total phenolic content (TPC) of the extracts was determined by the Folin-Ciocâlteu method with some modifications. The results were expressed in gallic acid equivalents on dry material plant (GAE; mg/g dry weight material plant $=$ d.w.) $[16,17]$.

The quantitative determination of flavonoids was performed using the spectrophotometric aluminium chloride method. The percentage of flavonoids was expressed in rutin equivalents (RE; $\mathrm{mg} / \mathrm{g}$ d.w.) $[16,17]$. The caffeic acid derivatives content was determined using the Arnow's spectrophotometric method. The phenolic acids content was expressed as caffeic acid equivalents (CAE; mg/g d.w.) [16, 17].

Antioxidant Activity Test

$D P P H$ free radical method is the most often used antioxidant assay. The absorbance was measured at $517 \mathrm{~nm}$. The antiradical activity was expressed as $\mathrm{IC}_{50}$ $(\mu \mathrm{g} / \mathrm{mL})$, that is the concentration of vegetal material required to cause a 50\% DPPH inhibition [18].

FRAP method uses the reduction of the ferric to the ferrous ion in a complex formed with iron, of the radical 2,4,6-tripyridyl-s-triazine. Depending on the concentration of antioxidant compounds in the sample, the colour of the complex is changed and absorbance is measured at $593 \mathrm{~nm}$. The results are expressed as $\mathrm{mM}$ Trolox equivalent/100 $\mathrm{mL}$ extract, on the basis of a calibration curve using a Trolox standard [19, 20]. Haemoglobin/Ascorbate Peroxidase activity inhibition (HAPX) assay. The haemoglobin ascorbate peroxidase activity (HAPX) assay was performed following the procedure described by Mot et al. [21]. Ascorbate $(120 \mu \mathrm{M})$, peroxide $(451 \mu \mathrm{M})$ and diluted extracts $(5 \mu \mathrm{L})$ were mixed with met haemoglobin $(6 \mu \mathrm{M})$ and the reaction was monitored at $405 \mathrm{~nm}$, the wavelength specific for met haemoglobin. The extracts were diluted from the stock solutions as follows: 100-timed diluted S. verticillata, S. aethiopis, S. austriaca and $50 \%$ S. sclarea, S. nutans, S. nemorosa. An increase in the inhibition time reflects the antioxidant capacity of the tested extracts. The percentage of the inhibition time was transformed to caffeic acid equivalents (CAE) using a calibration curve $\left(\mathrm{R}^{2}=0.99\right)$ with caffeic acid standard solutions of $0-60 \mu \mathrm{M}$.

Statistical Analysis

The samples have been analysed in triplicate or more; the average of the relative SD and the correlation (the correlation matrices) have been calculated using the Excel software package.

\section{Results and Discussion}

The HPLC profile of polyphenolic compounds (Table I) revealed the presence of 13 phenolic compounds in 
FARMACIA, 2019, Vol. 67, 5

the studied species. Five phenolic acids (caftaric, caffeic, chlorogenic, $p$-coumaric, ferulic acids), four flavonoid glycosides (hyperoside, isoquercitrin, rutin, quercitrin) and four flavonoidic aglycones (quercetin, luteolin, kaempferol and apigenin) were identified. Two flavonoidic aglycones, luteolin and apigenin were found in all the samples and the highest concentration was determined in S. austriaca $(6379.9 \pm 2.83 \mu \mathrm{g} / \mathrm{g}$ and $1214.6 \pm 1.64 \mu \mathrm{g} / \mathrm{g}$, respectively). Among flavonoid glycosides, isoquercitrin and rutin were determined in significant concentrations. Rutin, one of the most common flavonoid glycosides was detected in low amounts in all species (from $56.0 \pm 0.10 \mu \mathrm{g} / \mathrm{g}$ to $367.8 \pm 0.54 \mu \mathrm{g} / \mathrm{g}$ ). Isoquercitrin was found in the largest amount in S. sclarea $(2208.0 \pm 1.80 \mu \mathrm{g} / \mathrm{g})$. Caffeic acid was also identified in all samples and the highest concentration was found in S. sclarea $(776.5 \pm 1.12 \mu \mathrm{g} / \mathrm{g})$, followed by $S$. verticilatta $(741.5 \pm$ $1.31 \mu \mathrm{g} / \mathrm{g})$. For $S$. nutans, $p$-coumaric and ferulic acids were quantitated in significant concentrations (399.2 \pm $0.25 \mu \mathrm{g} / \mathrm{g}$ and $207.39 \pm 0.15 \mu \mathrm{g} / \mathrm{g}$, respectively).

Table I

The HPLC analyses of polyphenolic compounds

\begin{tabular}{|l|c|c|c|c|c|c|c|c|}
\hline \multicolumn{1}{|c|}{ Compound } & $\begin{array}{c}\boldsymbol{m} / \boldsymbol{z} \\
\mathbf{v a l u e}\end{array}$ & $\begin{array}{c}\mathbf{t}_{\mathbf{R}} \pm \mathbf{S D} \\
\mathbf{m i n}\end{array}$ & $\begin{array}{c}\text { S. aetiopsis } \\
\boldsymbol{\mu g} / \mathbf{g} \text { d.w. }\end{array}$ & $\begin{array}{c}\text { S. austriaca } \\
\mathbf{g} / \mathbf{g} \text { d.w. }\end{array}$ & $\begin{array}{c}\text { S. sclarea } \\
\boldsymbol{\mu g} / \mathbf{g ~ d . w .}\end{array}$ & $\begin{array}{c}\text { S. } \text { nutans } \\
\boldsymbol{\mu g} / \mathbf{g ~ d . w .} .\end{array}$ & $\begin{array}{c}\text { S. verticilatta } \\
\boldsymbol{\mu g} / \mathbf{g} \text { d.w. }\end{array}$ & $\begin{array}{c}\text { S. } \text { nemorosa } \\
\boldsymbol{\mu g} / \mathbf{g} \text { d.w. }\end{array}$ \\
\hline Caftaric acid & 311 & $3.45 \pm 0.05$ & $<0.02$ & $<0.02$ & $<0.02$ & $<0.02$ & $<0.02$ & $\mathrm{NF}$ \\
\hline Caffeic acid & 179 & $6.25 \pm 0.04$ & $<0.02$ & $615.0 \pm 0.55$ & $776.5 \pm 1.12$ & $<0.02$ & $741.5 \pm 1.31$ & $<0.02$ \\
\hline Chlorogenic acid & 353 & $6.43 \pm 0.05$ & $<0.02$ & $\mathrm{NF}$ & $\mathrm{NF}$ & $<0.02$ & $\mathrm{NF}$ & $<0.02$ \\
\hline$p$-coumaric acid & 163 & $9.48 \pm 0.08$ & $44.1 \pm 0.10$ & $32.1 \pm 0.07$ & $74.2 \pm 0.18$ & $399.2 \pm 0.25$ & $55.7 \pm 0.10$ & $146.4 \pm 0.22$ \\
\hline Ferulic acid & 193 & $12.8 \pm 0.10$ & $55.7 \pm 0.19$ & $\mathrm{NF}$ & $60.8 \pm 0.16$ & $207.4 \pm 0.15$ & $\mathrm{NF}$ & $182.1 \pm 0.31$ \\
\hline Hyperoside & 463 & $18.60 \pm 0.12$ & $<0.02$ & $<0.02$ & $<0.02$ & $<0.02$ & $<0.02$ & $<0.02$ \\
\hline Isoquercitrin & 463 & $20.29 \pm 0.10$ & $<0.02$ & $<0.02$ & $2208.0 \pm 1.80$ & $43.57 \pm 0.08$ & $713.1 \pm 1.10$ & $<0.02$ \\
\hline Rutin & 609 & $20.76 \pm 0.15$ & $115.4 \pm 0.25$ & $367.8 \pm 0.54$ & $\mathrm{NF}$ & $323.2 \pm 0.26$ & $56.0 \pm 0.10$ & $263.8 \pm 0.45$ \\
\hline Quercitrin & 447 & $23.64 \pm 0.13$ & $<0.02$ & $<0.02$ & $\mathrm{NF}$ & $\mathrm{NF}$ & $<0.02$ & $\mathrm{NF}$ \\
\hline Quercetin & 301 & $27.55 \pm 0.15$ & $\mathrm{NF}$ & $<0.02$ & $\mathrm{NF}$ & $\mathrm{NF}$ & $\mathrm{NF}$ & $\mathrm{NF}$ \\
\hline Luteolin & 285 & $29.64 \pm 0.15$ & $39.8 \pm 0.07$ & $6379.9 \pm 2.83$ & $779.6 \pm 1.10$ & $88.2 \pm 0.10$ & $74.4 \pm 0.13$ & $67.5 \pm 0.17$ \\
\hline Kaempferol & 285 & $32.48 \pm 0.17$ & $\mathrm{NF}$ & $\mathrm{NF}$ & $\mathrm{NF}$ & $<0.02$ & $\mathrm{NF}$ & $\mathrm{NF}$ \\
\hline Apigenin & 279 & $33.10 \pm 0.15$ & $48.1 \pm 0.09$ & $1214.6 \pm 1.64$ & $293.2 \pm 0.23$ & $312.8 \pm 0.23$ & $48.1 \pm 0.16$ & $57.9 \pm 0.21$ \\
\hline
\end{tabular}

$\mathrm{NF}$ - not found, below limit of detection; Values are expressed as mean $\pm \mathrm{SD}(\mathrm{n}=3)$.

The highest amount of total polyphenols was determined in $S$. austriaca $(118.75 \pm 2.04)$; the most abundant in caffeic acid derivatives was $S$. verticillata $(39.14 \pm$ $0.32 \mathrm{mg} / \mathrm{g}$ ), while the content of flavonoids was highest in $(10.33 \pm 0.17 \mathrm{mg} / \mathrm{g}) S$. nutans (Table II). The quantitative composition of plant material could be influenced by the pedoclimatic conditions of the region where the plant grow. The different extraction methods and standards used for phenolic expression (tannic acid equivalents, TAE, rosmarinic acid equivalents, RAE, instead of gallic acid equivalents
GAE) may result in a decrease or an increase in the total phenolic content values $[10,22]$.

Previous reports have revealed a range of 20.2 - $575 \mathrm{mg}$ GAE/g d.w. for the total phenolic content in different Salvia species (S. aethiopis, S. austriaca, S. glutinosa, S. pratensis, S. ringens, S. verticillata) $[9,23]$. Our results fall within the area of these limits. A lot of research was done on $S$. officinalis and the reported content of polyphenolic compounds was $86.4 \mathrm{mg}$ TAE/g d.w. in the Iranian sample and $75.7 \pm 0.26 \mathrm{mg}$ RAE/g d.w.) in Romanian sample [7, 14].

Table II

The content of polyphenols

\begin{tabular}{|l|c|c|c|}
\hline \multicolumn{1}{|c|}{ Samples } & $\begin{array}{c}\text { TPC (mg GAE/g plant } \\
\text { material) }\end{array}$ & $\begin{array}{c}\text { Flavonoids (mg RE/g plant } \\
\text { material) }\end{array}$ & $\begin{array}{c}\text { Caffeic acid derivatives (mg CAE/g plant } \\
\text { material) }\end{array}$ \\
\hline S. aetiopsis & $22.25 \pm 0.24$ & $4.70 \pm 0.14$ & $17.22 \pm 0.22$ \\
\hline S. austriaca & $118.75 \pm 2.04$ & $7.68 \pm 0.16$ & $24.39 \pm 0.24$ \\
\hline S. sclarea & $46.00 \pm 0.32$ & $1.98 \pm 0.04$ & $26.003 \pm 0.21$ \\
\hline S. nutans & $29.75 \pm 0.28$ & $10.33 \pm 0.17$ & $18.627 \pm 0.24$ \\
\hline S. verticillata & $85.25 \pm 0.64$ & $1.67 \pm 0.03$ & $39.14 \pm 0.32$ \\
\hline S. nemorosa & $40.25 \pm 0.34$ & $1.18 \pm 0.04$ & $28.66 \pm 0.24$ \\
\hline
\end{tabular}

Alongside with the traditional methods used for the characterization of the antioxidant capacity (DPPH and FRAP), another new physiologically relevant method was applied here - the haemoglobin ascorbate peroxidase activity inhibition (HAPX) assay, based on the enzymatic properties of haemoglobin to reduce hydrogen peroxide in the presence of antioxidants via the high valent form of the iron, ferryl [18]. S. verticilatta presents the highest antioxidant capacity determined by DPPH $(42.923 \pm 4.81 \mu \mathrm{g} / \mathrm{mL})$, FRAP $(8044 \pm 4.81 \mathrm{mmol}$ Trolox $/ \mathrm{mg})$ and HAPX $(1074.3 \pm$ $836 \mathrm{mg} \mathrm{CAE}) / \mathrm{g}$ ) (Table III). After S. verticillatta, 
S. nemorosa followed S. sclarea by appear to have a good antioxidant capacity according to all three methods. S. nutans, S. austriaca and S. aetiopsis have the lowest antioxidant actvity. For $S$. verticillata there is a close correlation between the antioxidant capacity with the total polyphenolic content and with the caffeic acid derivatives content. The antioxidant capacity of $S$. sclarea and S. nemorosa are well correlated with the poyphenolic content, flavonoid and caffeic acid derivatives content (exception for the correlation of $S$. sclarea with the flavonoid content). For $S$. austriaca there is a correlation between FRAP method and caffeic acid derivatives content. Even if this extract has the highest total polyphenolic content and very high content of flavonoids, it does not have the highest antioxidant capacity measured by DPPH and HAPX. Also a lack of correlation is found for $S$. nutans between antioxidant capacity and the content of flavonoids. In previous studies the $\mathrm{IC}_{50}$ value of DPPH radical scavenging was reported to range from
7.7 to $192 \mu \mathrm{g} / \mathrm{mL}$ for $S$. officinalis extracts [10]. For the Romanian sample $\mathrm{IC}_{50}$ was $81.12 \pm 1.87 \mu \mathrm{g} / \mathrm{mL}$ and the HAPX value was $237.61 \pm 26.35 \mathrm{mg} \mathrm{RAE} / \mathrm{g}$ [14] Overall, one may note an excellent correlation (coefficients at $\sim 0.8$ or higher) between HAPX, FRAP and caffeic acid derivative contents, respectively. Hence, the higher FRAP or HAPX results in $S$. verticillata and $S$. sclarea may be assigned to higher contents of caffeic acid derivatives. On the other hand, all three parameters showed much weaker correlation coefficients with DPPH, flavonoids or total polyphenolics. In fact, the correlation coefficients between HAPX/FRAP/caffeic and DPPH or flavonoids are negative $(\mathrm{r}=-0.3 \sim-0.7)$. On the other hand, DPPH correlates reasonably well with the flavonoid content $(\mathrm{r} \sim 0.8)$. These general trends are in reasonable agreement with previous observations when comparing parameters obtained from various methods of measuring the antioxidant and pro-oxidant reactivities [24].

Table III

The antioxidant activity of Salvia species

\begin{tabular}{|l|c|c|c|}
\hline \multicolumn{1}{|c|}{ Samples } & DPPH IC $_{\mathbf{5 0}}(\boldsymbol{\mu g} \mathbf{g} / \mathbf{m L})$ & FRAP $(\mathbf{m m o l}$ Trolox/mg d.w.) & HAPX (mg CAE)/g \\
\hline S. aetiopsis & $158.76 \pm 0.82$ & $1399 \pm 5.01$ & $6.31 \pm 0.21$ \\
\hline S. austriaca & $123.14 \pm 0.70$ & $2066 \pm 4.81$ & $8.88 \pm 1.56$ \\
\hline S. sclarea & $97.67 \pm 0.56$ & $2791 \pm 4.81$ & $146.66 \pm 23.69$ \\
\hline S. nutans & $158.03 \pm 0.88$ & $1546 \pm 4.81$ & $62.2 \pm 7.31$ \\
\hline S. verticillata & $42.923 \pm 0.23$ & $8044 \pm 4.81$ & $1074.3 \pm 836.16$ \\
\hline S. nemorosa & $80.09 \pm 0.6$ & $2797 \pm 4.81$ & $91.2 \pm 10.34$ \\
\hline Quercetin & $5.62 \pm 0.33$ & - & - \\
\hline BHT & $16.2 \pm 0.42$ & - & - \\
\hline
\end{tabular}

All assays were performed in triplicate

\section{Conclusions}

The polyphenolic profile and the antioxidant activity for six Salvia species were evaluated in order to complete scientific data related to Salvia genus that may be important sources of natural antioxidants. During the phytochemical screening, there were revealed significant differences, both qualitative and especially quantitative, between these species. $S$. verticilatta, rich in polyphenols, had the higher antioxidant activity, by all the three used methods. S. austriaca, with high content of luteolin and apigenin, was less antioxidant. A good antioxidant activity for $S$. sclarea and $S$. nemorosa could be related to the high content of caffeic acid derivatives. Overall, the studied Salvia species could be considered important natural sources of active principles, in special polyphenols.

\section{References}

1. Chua LS, A review on plant-based rutin extraction methods and its pharmacological activities. $J$ Ethnopharmacol., 2013; 150(3): 805-817.

2. Orodan M, Vodnar DC, Toiu AM, Pop CE, Vlase L, Istudor V, Arsene AL, Phytochemical analysis, antimicrobial and antioxidant effect of some gemmotherapic remedies used in respiratory diseases. Farmacia, 2016; 64(2): 224-230.

3. Pop CE, Parvu M, Arsene AL, Pârvu AE, Vodnar DC, Tarcea M, Toiu AM, Vlase L, Investigation of antioxidant and antimicrobial potential of some extracts from Hedera helix L.. Farmacia, 2017; 65(4): 624-629.

4. Tamas M, Pop C, Martian A, Barbu-Tudoran L, Morphological Research on Indigenous Sambucus Species Pollen. Notulae Botanicae Horti Agrobotanici Cluj-Napoca, 2009, 37(1): 65-69.

5. Ciocârlan V, Illustrated flora of Romania. Pteridophyta et Spermatophyta. Edit. Ceres, Bucharest, 2009; 656-660, (available in Romanian).

6. Ghorbani A, Esmaeilizadeh M, Pharmacological properties of Salvia officinalis and its components. eJTCM, 2017; 7: 433-440.

7. Alizadeh A, Shaabani M, Essential oil composition, phenolic content, antioxidant and antimicrobial activity in Salvia officinalis L. cultivated in Iran. Adv Environ Biol., 2012; 6(1): 221-226.

8. Asadi S, Ahmadiani A, Esmaeili MA, Sonboli A, Ansari $\mathrm{N}$, Khodagholi $\mathrm{F}$, In vitro antioxidant activities and an investigation of neuroprotection by six Salvia species from Iran: a comparative study. Food Chem Toxicol., 2010; 48(5): 1341-1349.

9. Tosun M, Ercisli S, Sengul M, Ozer H, Polat T, Ozturk E, Antioxidant properties and total phenolic content of 
eight Salvia species from Turkey. Biol Res., 2009; 42: 175-181.

10. Jeshvaghani ZA, Rahimmalek M, Talebi M, Hossein Goli SA, Comparison of total phenolic content and antioxidant activity in different Salvia species using three model systems. Ind Crops Prod., 2015; 7: 74097414.

11. Tepe B, Sokmen M, Akpulat HA, Sokmen A, Screening of the antioxidant potentials of six Salvia species from Turkey. Food Chem., 2006; 95(2): 200-204.

12. Yumrutas O, Sokmen A, Ozturk N, Determination of in vitro antioxidant activities and phenolic compounds of different extracts of Salvia verticillata ssp. verticillata and spp. amasiaca from Turkey's flora. J Appl Pharm Sci., 2011; 1(10): 43-46.

13. Benedec D, Vlase L, Oniga I, Mot CA, SilaghiDumitrescu R, Hanganu D, Tiperciuc B, Crisan G, LC-MS analysis and antioxidant activity of phenolic compounds from two indigenous species of Mentha. Note I. Farmacia, 2013; 61(2): 262-267.

14. Benedec D, Hanganu D, Oniga I, Tiperciuc B, Olah NK, Raita O, Bischin C, Silaghi-Dumitrescu R, Vlase L, Assessment of rosmarinic acid content in six Lamiaceae species extracts and their antioxidant and antimicrobial potential. Pak J Pharm Sci., 2015; 28(6): 2297-2303.

15. Vlase L, Mocan A, Hanganu D, Benedec D, Gheldiu A, Crișan G, Comparative study of polyphenolic content, antioxidant and antimicrobial activity of four Galium species (Rubiaceae). Dig J Nanomater Biostruct., 2014; 9(3): 1085-1094.

16. Toiu A, Vlase L, Arsene AL, Vodnar CD, Oniga I, LC/UV/MS profile of polyphenols, antioxidant and antimicrobial effects of Ajuga genevensis L. extracts. Farmacia, 2016; 64(1): 53-57.

17. Vlase L, Mocan A, Hanganu D, Benedec D, Gheldiu AM, Crișan G, Comparative study of polyphenolic content, antioxidant and antimicrobial activity of four
Galium species (Rubiaceae). Dig J Nanomater Bios., 2014; 9(3): 1085-1094.

18. Hanganu D, Benedec D, Vlase L, Olah N, Damian G, Dumitrescu RS, Moț AC, Toma CC, Polyphenolic profile and antioxidant and antibacterial activities from two Trifolium species. Farmacia, 2017; 65(3): 449-453.

19. Thaipong K, Boonprakob U, Crosby K, CisnerosZevallos L, Comparison of ABTS, DPPH, FRAP, and ORAC assays for estimating antioxidant activity from guava fruit extracts. $J$ Food Compost Anal., 2006; 19: 669-675.

20. Olah NK, Osser G, Câmpean RF, Furtuna FR, Benedec D, Filip L, Raita O, Hanganu D, The study of polyphenolic compounds profile of some Rosmarinus officinalis L. extracts. Pak J Pharm Sci., 2016; 29(6): 2355-2361.

21. Mot AC, Bischin C, Damian G, Silaghi-Dumitrescu R, Antioxidant activity evaluation involving hemoglobinrelated free radical reactivity. Advanced Protocols in Oxidative Stress III. Methods in Molecular Biology, Springer Ed., New York, NY, USA, 2013.

22. Bettaieb I, Hamrouni-Sellami I, Bourgou S, Limam F, Marzouk B, Drought effects on polyphenol composition and antioxidant activities in aerial parts of Salvia officinalis L.. Acta Physiol Plant, 2011; 33: 1103-1111.

23. Stagos D, Portesis N, Spanou C, Mossialos D, Aligiannis N, Chaita E, Panagoulis C, Reri E, Skaltsounis L, Tsatsakis AM, Kouretas D, Correlation of total polyphenolic content with antioxidant and antibacterial activity of 24 extracts from Greek domestic Lamiaceae species. Food Chem Taxicol., 2012; 50: 4115-4124.

24. Mot AC, Coman C, Miron C, Damian G, Sarbu C, Silaghi-Dumitrescu R, An assay for pro-oxidant reactivity based on phenoxyl radicals generated by laccase. Food Chem., 2014; 143: 214-222. 